\title{
Institutional Quality, Financial Development and Inclusive Growth: Asymmetric Cointegration Approach
}

\author{
Olumuyiwa Ganiyu Yinusa ${ }^{1}$ \\ * Olalekan Bashir Aworinde ${ }^{2}$ \\ Ibrahim Abidemi Odusanya ${ }^{3}$
}

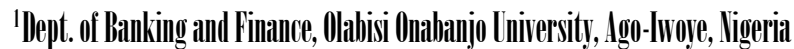

'Dept. of Rconomics, Pinn-Itlantic Lniversity, Lagos, ligeriia

"Ilept. of Pconomics, Olabisisi Oniabbinjo Iniversity, Lgo-Iwoge, ligeriia

\begin{abstract}
The study examined the nexus between institutional quality, financial development and inclusive growth in Nigeria for the period 1984-2017. The study employed asymmetric cointegration approach to study the long-run relationship of institutional quality, financial development and inclusive growth in Nigeria. The results of the study showed that there is a long-run relationship between institutional quality, financial development and inclusive growth in Nigeria. It was also found that adjustments process to equilibrium for institutional quality, financial development and inclusive growth were asymmetric in Nigeria. The study therefore concludes that institutional quality and financial development are crucial variables that influence inclusive growth in Nigeria.

Keywords: Finance-growth link, institutional quality, financial development, inclusive growth, asymmetric cointegration

JEL: C20, N2, 043
\end{abstract}

The measurement of growth in literature has continued to be evolving from the traditional measurement of economic progress that uses majorly the gross domestic product (GDP) and its variants (see Todaro and Smith, 2011) to more encompassing measures. The traditional measures find it difficult to capture many people from the poverty line. A failure which makes development economist and analyst to begin to query the suitability of these measures. The underlying assumption for the use of GDP and its variant as a measure of economic progress and welfare was predicated on the trickle-down hypothesis but economists found that this assumption is not absolute and then suggested another concept of well-being known as pro-poor growth. The idea behind this measure of growth is that growth must be poverty alleviating by reducing the number of poor people. That is, the benefit accruing from expansion of productive activities must be employed to get people out of poverty through government interventionist policies of income redistribution and spending instruments. However, the increasing rent seeking economy and expansive government portfolios (due to democratic governance) indicated that government policies directed towards poverty alleviation have either been ineffective or inadequate or both; therefore, necessitated another paradigm shift in the 
growth literature to inclusive growth. With inclusiveness, the growth generating process has an inbuilt mechanism to automatically cater for and include the poor in the society.

Inclusive growth is a multidimensional and complex concept and there is no consensus in the literature and in policy discussions on how it should be defined and measure. One possible way to define growth as inclusive has to do with absolute reduction in poverty associated with a creation of productive employment rather than direct income distribution schemes. Inclusive growth is expected to accommodate both the pace and pattern of growth (World Bank, 2009).

The relationship between financial development and economic growth has been a subject of considerable debate in the literature (Alaabed and Masih, 2016). There are however, different perspectives in the literature on the link between financial development and economic growth. While as an important extension, the earliest studies focused on the effect of financial development on economic growth, some studies were interested in the relative merits of a bank-based financial system and a market-based financial system on economic growth (see Akinlo and Akinlo, 2009; Allen and Gale, 1999; Atje and Jovanovich, 1993; Boot and Thakor, 1997; Levine and Zevros, 1998; Peia and Roszbach, 2015). Another strand of studies extended these works by stressing the non-linearity of the finance-growth nexus (Chen, Wu and Wen, 2013; Gazdar and Cherif, 2015; Alaabed and Masih, 2016). The notable earlier works on finance and growth along the Shumpeterian lines include Gurley and Shaw (1955), and Goldsmith (1969) and the financial liberalization thesis of Mckinnon (1973) and Shaw (1973). They all argued that financial development was crucial in determining economic growth. However, other studies have even put forward a bi-directional causality (e.g., Patrick, 1966; Ang, 2008). Some even suggested that the link between finance and growth can only be appreciated when a certain threshold level is reached (e.g., Law, Azmani-saini and Ibrahim, 2013; Andini and Andini, 2014, Gazdar and Cherif, 2015; Alaabed and Masih, 2016).

Recent studies have documented mixed and inconclusive result on the relationship between financial development and economic growth. Some studies provided evidence in support of positive relationship (see Chinaemerem and Chigbu, 2012; Nkoro and Uko, 2013; Waqabaca, 2004) others document a negative relationship (see Grundler and Weitzel, 2013; Jalil and Feridun, 2011; Maduka and Onwukam, 2013), while few studies found mixed results (see Al-Tamimi, Al-Awwad and Charif, 2002; Caporale et al., 2014; Pan and Wang, 2013).

Despite numerous studies investigating the finance-growth link, there are scanty studies linking institutional quality, financial development, and inclusive growth. Though there have been few studies on the either side linking finance-inclusive growth (see Greenwood and Jovanovich, 1990; Kirkpatrick, 2000) or finance-growth and institution (see Allen, Qian and Qian, 2005; Garretsen, Lensink and 


\section{Yinusa et al.}

Sterken, 2004; Gazdar and Cherif, 2015; Herwatz and Walle, 2014; Law et al., 2013), while others are on institution and growth (see Acemoglu et al., 2003; Easterly, Levine and Roodma, 2004; Rigobon and Rodrik, 2004) with quite contradicting findings. Another important issue is the measurement of growth, the traditional measurement of growth is gross domestic product (GDP) other measurement has been used in literature such as the inflation adjusted growth (Real GDP) and the GDP per capita which measures the individual share of the growth. However, due to the inherent limitations of these measurements, this study relies on one of the measurements of inclusive growth that revolves around prosperity sharing through productive employment. This study contributes to the existing literature by assessing the impact of financial development on inclusive growth with specific consideration of the quality of institutions. It is against the foregoing that this study examines the nexus between institutional quality, financial development, and inclusive growth with specific reference to Nigeria. Nigeria has the second most developed financial sector in Africa after South Africa but the poverty and inequality levels in the country seem very high. Nigeria is pervaded with several market imperfections such as macroeconomic imbalances, poor institutional quality, weak minority investor's protection, underdeveloped capital market, poor contract enforcement, and high level of corruption. Globally, Nigeria stands at 62 in the ranking of 189 economies on the strength of minority investor protection and ranks 140 in the ranking of 189 economies on the ease of enforcing contracts and ranks high in terms of corruption perception index (World Bank, 2014).

It is against this backdrop that current study examines the nexus between institutional quality, financial development, and inclusive growth in Nigeria. Thus, the justifications for this study are threefold. First, the study adds to empirical literature having adopted an improved method of data analysis using the asymmetric cointegration approach against the conventional symmetric approach to cointegration employed by Akinlo and Akinlo (2009), Alexiou, Tsaliki and Osman (2014), Jalil and Feridun (2011), and Nyasha, Gwenhure and Odhiambo (2016). Second, the study contributed significantly to the finance-growth debate in Nigeria by accounting for the role of institutional quality in enhancing the level of economic growth. Third, the findings and policy implications of this study are relevant to policy makers, investors and economists for financial market investment decision in the face of asymmetric information and low institutional quality.

Apart from the introduction, the rest of the paper is divided into six other sections: Section 2 centers on the review of theoretical and empirical literature. Section 3 describes data and methodology, section 4 presents the result and discussion of findings and sections 5,6 and 7 presents the conclusion, implications and future directions, respectively.

\section{LITERATURE REVIEW}




\section{Theoretical Underpinnings on Finance and Growth}

Various views that exist on finance-growth link have been built on four strands. The first strand is based on the work of Schumpeter (1911) who attached a greater importance to the role played by financial development in the growth process. This view is known as "Supply-leading hypothesis" which is otherwise known as "Finance-led growth hypotheses". According to the proponents of this view, financial development facilitates mobilization of productive savings, efficient resource allocation, reduce information asymmetry, and improve risk management which will in turn promote and help entrepreneur's innovation process. This effect could create a favorable macroeconomic framework for strong economic growth (see Akinlo and Egbetunde, 2010; Beck and Levine, 2002; Christopoulos and Tsionas, 2004; King and Levine, 1993; Mckinnon, 1973; Shaw, 1973) among others. The second strand is based on the work of Robinson (1952) who postulated that financial deepening is growth dependent. It suggests that causality is from economic growth to financial development as increase in demand for financial service deepens, the financial sector in the economy progresses (see Adeyeye et al., 2015; Calderón and Liu, 2002; Goldsmith, 1969; Jung, 1986; Odhiambo, 2004, 2009). This view, known as the "Demand-following hypothesis" or alternatively "growth-led finance hypothesis", opines that when economy expands, there is a rise in macroeconomic activities yielding resultant development of the financial sector (Adeyeye et al., 2015; Singh, 1999).

Another dimension to finance-growth link is the "bidirectional causality" otherwise known as "feedback hypothesis" propounded by Patrick (1966) who ascribes equal importance to both financial and real sector of the economy since it assumes a positive two-way causal relationship between finance and growth. This view postulates that causal link between financial development and economic growth alternates as economy develops. In the early stage, supply-leading process holds and as the economy grows, it fades away and demand-following prevails (see Akinlo and Akinlo, 2009; Ang, 2008). The fourth strand is the "neutrality view" which specifies no significant causal relationship between financial development and economic growth. According to this view neither of these two phenomena has significant effect on the other (see Shan, Morris and Sun, 2001).

\section{Theoretical Underpinnings on Financial Development, Institutional Quality and Growth}

It is important to point out that economic theory have conspicuously overlooked the link between Institutional quality and inclusive growth. Some earlier works linking finance-growth to institutional quality (Acemoglu et al., 2003; Al-Yousif, 2002; Arestis and Demetriades, 1996; Demetriades and Andrianova, 2004; Demetriades and Law, 2006; North, 1990) suggest "better finance-more growth theory" and argue that financial system embedded in sound institutional framework is more important for growth. Arguably, an increase in financial development captured by standard financial development 


\section{Yinusa et al.}

indicators may not result in increased growth due to corruption in the financial system or diversion of credit to an unproductive sector as a result of political interference. Therefore, finance-growth cannot be generalized across countries because economic policies are country-specific and their success depends on the institutions implementing them (Al-Yousif, 2002). The importance of institution as a growth determinant has been confirmed in literature (see Alexiou, Tsaliki and Osman, 2014). According to the "institutional quality hypothesis" the institutional framework within which the various economic agents interact with one another affects economic development. Ferrini (2012) asserted that institutions also spur growth through economic transactions. He argued that the costs of economic transactions propel economic growth in the form of contracts and contract enforcement, common commercial codes, and increased availability of information, all of which reduce the costs of transactions, risk, and uncertainty and thus increase the level of growth. In summary financial development advances the level of growth, and that institutional quality helps to facilitate improvement in the level of growth in Nigeria.

Owing from the above there is a link between growth, financial development and institutional quality. This is because countries with a proper financial development such as access to credit facilities to the private sector, high level of solvency and adequate developed capital market will promote inclusive growth. However, there is the possibility that high level of financial development might not translate to inclusive growth if there is lack of institutions. Thus, countries with high level of ease of doing business coupled with good investment profile, low level of corruption as well as the maintenance of law and order will engender financial development and then lead to inclusive growth. Thus, the transmission mechanism is that countries with good institutional quality such as high investment profile, maintenance of law and order and low level of growth will increase the level of financial development and financial development now will lead to inclusive growth.

\section{Empirical Review}

There is dearth of studies linking institutional quality, financial development, and inclusive growth. Though there have been few studies on the either side linking finance-inclusive growth (see Greenwood and Jovanovich, 1990; and Kirkpatrick, 2000) or finance-growth and institution (see Allen et al., 2005; Garretsen et al., 2004; Gazdar and Cherif, 2015; Herwatz and Walle, 2014; Law et al., 2013). Meanwhile others focused on institution and growth (see Acemoglu et al., 2003; Easterly et al., 2004; Rigobon and Rodrik, 2004). Findings from these studies have been controversial.

Chang (2002) tested the competing hypotheses of supply-leading and demand-following for Mainland China. Findings suggest that there is independence between financial development and economic growth. It supports neither supply-leading nor demand-following hypothesis. Peia and 
Roszbach (2015) re-examined the empirical relationship between financial and economic development while taking their dynamics into account and differentiating between stock market and banking sector development. The results indicate that among advanced economies, stock market development generally caused economic development while the causality between banking sector development and growth goes in reverse direction, most of the time. The results also suggest that the extensive empirical evidence that finance causes growth is sensitive to the type and dominance of a particular financial institution. The findings complement recent studies suggesting that not just the size, but also the structure of financial system may matter for growth.

Murinde and Eng (1994) investigated two competing hypotheses regarding financial development and economic growth. Evidence from the study largely supports the supply-leading hypothesis only when broad monetary aggregates and monetization variable are used as proxy for financial development. They concluded that there is plausible case for those economies which intend to adopt a financial restructuring strategy driven by a supply-leading policy stance that involves enhanced monetization of the economy and bank intermediation. Gazdar and Cherif (2015) investigated on how financial development affects economic growth in (Middle East and North Africa) MENA countries and examined how the responsiveness of economic growth to financial development depends upon the indicator of institutional quality. The result indicated that most indicators of financial development have significant negative effect on economic growth. However, the sign of the coefficient of interaction variable is significantly positive. This provides strong evidence that institutional quality mitigates the negative effect of financial development on economic growth i.e., financial development can promote economic growth only in countries with sound institutional environment. The threshold for the four institutional variables is $0.60,0.57,0.59$, and 0.55 .

Abedifar, Hassan and Tarazi (2016) investigated the relative importance of Islamic banks, alongside their conventional counterparts, in relation to banking and financial development and economic welfare. The result revealed significant positive relationship between the market share of Islamic banks and the development of financial intermediation, financial deepening, and economic welfare, particularly in low income or predominantly Muslim countries and countries with a comparatively higher uncertainty avoidance index. Additionally, the results revealed that a greater market share of Islamic banks is associated with higher efficiency of conventional banks. Demetriades and Law (2004) tested whether the interaction between institutional quality and financial development has a separate positive impact on economic growth, over and above the effect of the levels of financial development and institutional quality. The result suggested that financial development has larger effect on growth when financial system is embedded within a sound institutional framework. This 


\section{Yinusa et al.}

is particularly true for poor countries. Its effect is particularly large when institutional quality is high. For high-income countries the effect of financial development is smaller than middle-income countries; however, even in these countries its effect appears to be much larger when institutional quality is high.

Garretsen et al. (2004) analyzed whether societal norms, in addition to legal institution, have an impact on financial development. The result indicates that societal norms are indeed important in explaining stock market capitalization, while this is not the case for the supply of bank credit. Law et al. (2013) examined whether the growth effect of financial development in countries with distinct level of institutional development differs. The result indicates the presence of a significant institution threshold in the financial development-economic growth nexus. For institutions below the threshold, financial development has an insignificant effect on growth. The growth effect however turned out to be positive and significant for institutions above the threshold level. These findings suggest that financial development-growth nexus is contingent on institutions where financial development promotes growth after certain threshold level has been exceeded. It is deducible from the result that policy makers should improve the level of institutional development to explore the benefits of financial sector reforms in promoting economic growth.

Andini and Andini (2014) argued that the effect of a financial stimulus on growth can vary along quantiles of the conditional growth distribution. The result indicated that countries in the upper tail of the conditional growth distribution react more than countries in the lower tail to the same financial stimulus i.e., if two countries have the same observed and time-invariant characteristics but differ in growth, an increase in private credit as share of GDP in the same amount in the two countries may increase their difference in growth in favor of the country growing faster. Hence, a given policy stimulating private credit, despite equally applied to countries with the same characteristics but different level of growth, may increase the average growth among these countries but at the cost of higher within-countries growth inequality.

Law and Singh (2014) provide new evidence on the finance-growth relationship. The empirical result suggests a threshold effect in finance-growth relationship. Level of financial development is beneficial to a certain threshold; beyond the threshold level, further development of finance tends to affect growth adversely. They therefore suggested an optimal level of finance that is more crucial for economic growth.

Breitenlechner, Gachter and Sindermann (2015) linked two contradicting strands in the literature of a positive finance-growth nexus and the financial cycle and credit boom. The result confirms a positive long-run relationship between financial development and economic growth during the noncrisis period; a linear, negative relationship was however found during the financial crises times. Thus, 
higher level of financial intermediation increases the cost of crisis in terms of GDP per capita growth in a linear manner. A threshold of 80 percent $(130 \%)$ was also found for private credit and liquid liabilities as measures of financial development.

Jalil and Feridun (2011) investigated the effect of financial sector development on economic growth in Pakistan. The result revealed the presence of positive and significant relationship between financial development and economic growth. It draws attention to the key function of financial systems in a developing economy such as Pakistan. Alexious, Tsaliki and Osman (2014) explored the extent to which conventional methods used in the majority of relevant growth studies can successfully interpret the economic performance of Sudan. It was found that the quality of the institutional environment is one of the most important factors defining economic prosperity. They suggest that institutional reform is crucial for economic growth. Similarly. Odhiambo (2008) examined the direction of causality between financial development and economic growth in Kenya. The researcher found that causality between finance and growth is sensitive to the choice of measure of financial development. The research concluded that the demand-following hypothesis response tend to predominate in Kenya.

Nyasha, Gwenhure and Odhiambo (2016) investigated the dynamic causal linkage between bankbased financial development and economic growth in Ethiopia. Bidirectional causality was found in the short-run between financial development and economic growth, unidirectional causality from financial development to economic growth was however found in the long-run. The study concludes that policies aimed at enhancing financial development and growth should be pursued in the short-run but policies should be targeted at developing banking-sector in the long-run to sustain the growth path.

A review of methodologies adopted by past studies shows that most of them adopted a dynamic panel analysis (see Abedifar et al., 2016; Andini and Andini, 2014; Catrinescu et al., 2009; Demetriades and Law, 2004). Some employed vector autoregressive (VAR), vector error correction models (VECM) (see Boulila and Trabelsi, 2004; Chang and Caudill, 2005; Murinde and Eng, 1994), and dynamic and pair wise Granger causality with VECM (Adeyeye et al., 2015; Odhiambo, 2008). Likewise, some used Hansen threshold regression model (see Alaabed and Masih, 2016; Law et al., 2013) as well as autoregressive distributed lag (ARDL) bound testing approach (see Akinlo and Akinlo, 2009; Alexious et al, 2014; Nyasha et al, 2016). Herwatz and Walle (2014) employed the dynamic and fully modified OLS. However, the use of asymmetric cointegration makes our study unique by accounting for asymmetries in the relationship of the variables in the long-run which previous studies largely overlooked.

Arising from the literature above on financial development, institutional quality and inclusive growth, two null hypotheses have been proposed: 


\section{Yinusa et al.}

$\mathrm{H}_{01}$ : Financial development does not increase the level of inclusive growth in Nigeria.

$\mathrm{H}_{02}$ : Institutional quality does not improve the level of inclusive growth in Nigeria.

\section{METHODOLOGY}

\section{Sample and Procedure}

The study used yearly data for a period of 34 years from 1984 to 2017 . The key variables of interest in this paper are inclusive growth, financial development, and institutional quality. The natural logarithm of GDP per person employed was used as a proxy for inclusive growth (LGDPPPE), this is used so as to reveal the two factors of average opportunities available to the population and how these opportunities are distributed in the population (Oyinlola and Adedeji 2019; Raheem, Isah and Adedeji, 2018). The financial development variables are credit to private sector expressed as a percentage of the GDP (CPS), liquid liability (LLB) is the ratio of liquid liabilities of financial system as a percentage of the GDP, market capitalization (MCAP) which is an indicator for market size and is the ratio of value of domestic equities to GDP (Bittencourt, 2012; Demirgüç-Kunt and Levine, 1999). The institutional variables are investment profile (INVP) which is the assessment of factors affecting the risk to investment using three components of contract viability, profits repatriation, and payment delays; corruption (CORRP) is the assessment of corruption within the political system using the following parameters actual or potential corruption in the form of excessive patronage, nepotism, job reservations, "favor-for favors", secret party funding, and suspiciously close ties between politics and business. The third institutional variable is law and order (LAW), the law assesses the strength and impartiality of the legal system are considered, while the order element is an assessment of popular observance of the law (Gazdar and Cherif, 2015; Muye and Muye, 2017). The GDP per person employed was sourced form the World Bank Development Indicators, whereas credit to private sector, liquid liability, market capitalization, government expenditure, and the gross domestic product were sourced from the CBN statistical bulletin and the institutional variables sourced from the International Country Risk Guide (ICRG).

To examine the asymmetric cointegrating relationship for institutional quality, financial development and inclusive growth in Nigeria, the following estimation strategy was employed. First, the study examined the time series properties of the series using the augmented Dickey Fuller (ADF) and the Phillip-Perron (PP) unit root test. Second, if the variables were stationary in their first differences, the study proceeds by examining the long-run relationship between institutional quality, financial development, and inclusive growth. Third, if cointegration is found then, the study uses the threshold autoregressive (TAR) and momentum threshold autoregressive (MTAR) models of Enders and Siklos 
(2001) as there could be some asymmetries in the adjustment process towards the long-run equilibrium. Fourth, if TAR and MTAR cointegration is not found and the model is symmetric, the study proceeds with the analysis of a standard VECM. On the contrary, given that there are asymmetries in the adjustment process towards the long-run equilibrium, the study then estimates a threshold VECM.

\section{Empirical Model and Estimation Technique}

This paper examined the link between institutional quality, financial development and inclusive growth in Nigeria following the work of Allen, Qian and Qian (2005), Gazdar and Cherif (2015), Jalil and Feridun (2011), and Law et al. (2013) among others with modifications. To examine the possibility of asymmetric adjustments in the series, the study used the Enders and Siklos (2001) asymmetric cointegration methodology. The relationship between institutional quality, financial development and Inclusive growth is specified as:

$$
\begin{aligned}
L G D P P P E_{t}= & \alpha_{0}+\alpha_{1} C P S_{t}+\alpha_{2} L L B_{t}+\alpha_{3} M C A P_{t} \\
& +\alpha_{4} I N V P_{t}+\alpha_{5_{t}} C_{\text {CORPP }}+\alpha_{6} L A W_{t}+\varepsilon_{t}
\end{aligned}
$$

where logarithm of GDP per person employed (LGDPPPE). The independent variables are credit to private sector as percentage of the GDP (CPS), liquid liability as a percentage of the GDP (LLB), market capitalization as a percentage of the GDP (MCAP). The institutional variables are investment profile (INVP), level of corruption index (CORRP), and law and order (LAW). The specified model in equation (1) is tested for a long-run relationship. After estimating the model, the obtained residuals series $\varepsilon_{t}$ are subjected to a unit root test that is of the form:

$$
\Delta \varepsilon_{t}=\rho \varepsilon_{t-1}+\mathrm{v}_{t}
$$

where $\varepsilon_{t}$ is the residuals from equation (1) and assumed to be purely white noise with a zero mean and a constant variance while $v_{t}$ is an independent and identically distributed disturbance with zero mean. If the null hypothesis of $\rho=0$ can be rejected, then $\varepsilon_{t}$ is stationary. The model in equation (2) assumes a symmetric adjustment process and, therefore, change in $\varepsilon_{t}$ is $\rho \varepsilon_{t-1}$ regardless of whether $\varepsilon_{t-1}$ is positive or negative. However, if inclusive growth, institutional quality and financial development show asymmetric adjustment behavior, therefore, the model in equation (2) is misspecified. Enders and Siklos (2001) proposed two tests of asymmetries; a threshold autoregressive (TAR) model and a momentum threshold autoregressive (MTAR) model. Following Enders and Siklos (2001) two different hypotheses can be tested. The TAR model is given as: 


$$
\Delta \varepsilon_{t}=I_{t} \rho_{1} \varepsilon_{t-1}+\left(1-I_{t}\right) \rho_{2} \varepsilon_{t-1}+\mathrm{v}_{t}
$$

where $I_{t}$ is the Heaviside indicator such that:

$$
I_{t}=\left\{\begin{array}{ll}
1 & \text { if } \varepsilon_{t-1} \geq \tau \\
0 & \text { if } \varepsilon_{t-1}<\tau
\end{array}\right\}
$$

where $\tau$ is the value of the threshold and it is endogenously determined using the Chan (1993) technique. The method arranges the values of $\varepsilon_{t}$ and $\Delta \varepsilon_{t}$ for the TAR and the MTAR models, respectively, in ascending order and exclude the smallest and the largest 15 percent, making $\tau$ consistent estimate which yields the smallest residual sum of squares over the remaining 70 percent. The MTAR model takes the following form:

$$
\Delta \varepsilon_{t}=M_{t} \rho_{1} \varepsilon_{t-1}+\left(1-M_{t}\right) \rho_{2} \varepsilon_{t-1}+\mathrm{v}_{t}
$$

where $M_{t}$ is the Heaviside indicator such that:

$$
M_{t}=\left\{\begin{array}{l}
1 \text { if } \Delta \varepsilon_{t-1} \geq \tau \\
0 \text { if } \Delta \varepsilon_{t-1}<\tau
\end{array}\right\}
$$

The necessary condition for the stationarity of $\varepsilon_{t}$ is that $\rho_{1}<0, \rho_{2}<0$ and $\left(1+\rho_{1}\right)\left(1+\rho_{2}\right)<1$. If $\varepsilon_{t-1}$ is above the long-run equilibrium value, then adjustment is at the rate of $\rho_{1}$, but if $\varepsilon_{t-1}$ is below the long-run equilibrium value then adjustment is at the rate of $\rho_{2}$. However, adjustment is symmetric if $\rho_{1}=\rho_{2}$. Therefore, where the null hypothesis $\mathrm{H}_{0}:\left(\rho_{1}=\rho_{2}\right)$ is rejected, then the TAR model can be used to capture the signs of the asymmetries. The MTAR model is useful when the adjustment exhibits more momentum in one direction than the other. That is, the speed of adjustment depends on whether $\varepsilon_{t-1}$ is increasing or decreasing. If $\left|\rho_{1}\right|<\left|\rho_{2}\right|$, then increases in $\Delta \varepsilon_{t-1}$ may tend to persist, whereas decreases revert back to the threshold are done quickly.

Enders and Siklos (2001) proposed two sets of tests to test the null hypothesis $H_{0}: \rho_{1}=\rho_{2}$ in equation (5) for both the TAR and MTAR models. The $f$-statistic does not follow the standard distribution, consequently, $\emptyset_{u}$ from the estimated TAR model is compared with $\emptyset^{*}{ }_{u}$ for the MTAR model provided in Enders and Siklos (2001). Since there is no presumption whether to use TAR or MTAR model, the recommendation is to use the information criteria to determine the better model among the two. If the residuals in equations (3) and (5) are serially correlated, they are: 


$$
\begin{gathered}
\Delta \varepsilon_{t}=I_{t} \rho_{1} \varepsilon_{t-1}+\left(1-I_{t}\right) \rho_{2} \varepsilon_{t-1}+\sum_{i=1}^{P} \beta_{i} \Delta \varepsilon_{t-i}+\mathrm{v}_{t} \\
\Delta \varepsilon_{t}=M_{t} \rho_{1} \varepsilon_{t-1}+\left(1-M_{t}\right) \rho_{2} \varepsilon_{t-1}+\sum_{i=1}^{P} \gamma_{i} \Delta \varepsilon_{t-i}+\mathrm{v}_{t}
\end{gathered}
$$

Model in equation (7) represents the new TAR model while the one in equation (8) is the modified MTAR model, respectively. The asymmetric version of the error correction model (ECM) is formulated as equation (9) and (10).

$$
\begin{aligned}
\triangle L G D P P P E_{t}= & \rho_{11} I_{t} \hat{\varepsilon}_{t-1}+\rho_{12}\left(1-I_{t}\right) \hat{\varepsilon}_{t-1}+\sum_{i=1}^{p} \delta_{1} \Delta C P S_{t-i}+\sum_{i=1}^{p} \gamma_{k} \Delta L L B_{t-i} \\
& +\sum_{\substack{i=1 \\
p}}^{p} \propto_{k} \Delta M C A P_{t-i}+\sum_{i=1}^{p} \beta_{k} \Delta I N V P_{t-i}+\sum_{i=1}^{p} \theta_{k} \Delta \operatorname{CORRP}_{t-i} \\
& +\sum_{i=1}^{p} \varphi_{k} \Delta L A W_{t-i}
\end{aligned}
$$

$\triangle L G D P P P E_{t}=\rho_{11} M_{t} \hat{\varepsilon}_{t-1}+\rho_{12}\left(1-M_{t}\right) \hat{\varepsilon}_{t-1}+\sum_{i=1}^{p} \delta_{1} \Delta C P S_{t-i}+\sum_{i=1}^{p} \gamma_{k} \Delta L L B_{t-i}$$$
+\sum_{i=1}^{p} \propto_{k} \Delta M C A P_{t-i}+\sum_{i=1}^{p} \beta_{k} \Delta I N V P_{t-i}+\sum_{i=1}^{p} \theta_{k} \Delta \operatorname{CORRP}_{t-i}
$$$$
+\sum_{i=1}^{p} \varphi_{k} \Delta L A W_{t-i}
$$

The ECM represented by the parameters $\rho_{i t}$ captures the speed of adjustments back to the equilibrium. The speed of adjustment for any positive deviation from long-run equilibrium (depending on the attractor indicator) is denoted by $\rho_{11}$. In the same vein, the of speed of adjustment of any negative deviations as defined by the attractor indicator, is known as $\rho_{12}$.

\section{RESULTS}

Table 1 contains the summary statistics for all the variables, showing that the logarithm of the GDP per person which is used as a proxy for inclusive growth is growing overtime with its minimum value being 3.91. In addition, credit to the private sector as a percentage of the GDP have a mean of 11.6 percent. It was also shown that all the variables were not constant particularly the institutional variables 


\section{Yinusa et al.}

of investment profile, corruption and law and order, thus, the need to check for the order of integration of the series. The standard deviation of all the variables also suggest that they were not different from their means. In addition, the study found that the Jarque-Bera statistic for five of the variables included in the model were non-normal, this further suggest the rationale for the use of asymmetric cointegration. Prior to checking the order of integration of the series, the study also examined the degree of association between the explanatory variables and the dependent variable using the correlation coefficient.

\begin{tabular}{|c|c|c|c|c|c|c|c|c|c|c|}
\hline \multirow[b]{2}{*}{ Variables } & \multirow[b]{2}{*}{ Mean } & \multirow[b]{2}{*}{ Median } & \multirow[b]{2}{*}{ Maximum } & \multicolumn{3}{|c|}{ Std. } & \multicolumn{4}{|c|}{ Jarque- } \\
\hline & & & & Minimum & Dev. & Skewness & Kurtosis & Bera & & \\
\hline LGDPPPE & 4.08 & 3.99 & 4.29 & 3.91 & 0.13 & 0.47 & 1.47 & 4.53 & 0.10 & 34 \\
\hline CPS & 11.57 & 8.23 & 23.08 & 6.22 & 5.95 & 0.90 & 2.02 & 5.93 & 0.05 & 34 \\
\hline LLB & 28.56 & 20.97 & 121.54 & 12.14 & 24.17 & 3.21 & 12.52 & 186.62 & 0.00 & 34 \\
\hline MCAP & 11.04 & 7.21 & 39.95 & 3.05 & 8.55 & 1.29 & 4.81 & 14.10 & 0.00 & 34 \\
\hline INVP & 5.68 & 6.00 & 7.00 & 4.00 & 0.79 & -0.47 & 2.43 & 1.71 & 0.43 & 34 \\
\hline CORRP & 1.60 & 1.50 & 2.00 & 1.00 & 0.37 & -0.33 & 1.93 & 2.24 & 0.33 & 34 \\
\hline LAW & 2.02 & 2.00 & 3.00 & 1.00 & 0.72 & 0.06 & 1.86 & 1.85 & 0.40 & 34 \\
\hline
\end{tabular}

Source: Authors' Computation

Table 1. Descriptive Statistics for Inclusive Growth, Institutions and Financial Development

From Table 2, credit to private sector as a percentage of the GDP (CPS), liquid liability as a percentage of the GDP (LLB), market capitalization as a percentage of the GDP (MCAP) and investment profile (INVP) have positive association with GDP per person employed (LGDPPPE). Meanwhile level of corruption index (CORRP) and law and order (LAW) have negative association with inclusive growth in Nigeria. Table 3 (see Appendix-I) presents the unit root tests. Using the augmented Dickey- Fuller test (ADF), and the Phillips and Perron test (PP), the reported results indicate that the null of unit root could not be rejected on the series levels but were rejected in their first difference, thus paving way to test for cointegration.

Subsequently, linear cointegration tests were conducted on the estimated model specified in equation (1), using the Johansen cointegration test the results in Table 4 (see Appendix-II) show that there is a long-run relationship between the inclusive growth, institutional quality, and financial development in Nigeria, thus, the null of no cointegration was rejected. The estimated cointegrating 


\begin{tabular}{|c|c|c|c|c|c|c|c|c|}
\hline Variables & LGDPPPE & LAW & $\overline{C P S}$ & CORRP & INVP & $\overline{L L B}$ & MCAP & $\overline{\text { VIF }}$ \\
\hline LGDPPPE & 1 & & & & & & & N/A \\
\hline LAW & -0.06 & 1 & & & & & & 1.09 \\
\hline CPS & $0.89^{*}$ & -0.02 & 1 & & & & & 2.82 \\
\hline CORRP & $-0.33^{\dagger}$ & -0.09 & -0.24 & 1 & & & & 1.43 \\
\hline INVP & $0.45^{\dagger}$ & 0.11 & $0.49^{* *}$ & 0.22 & 1 & & & 1.64 \\
\hline LLB & $0.58^{* *}$ & -0.03 & $0.60^{* *}$ & -0.21 & 0.2 & 1 & & 1.59 \\
\hline MCAP & $0.83^{* *}$ & 0.03 & $0.66^{* *}$ & $-0.36^{*}$ & $0.31^{\dagger}$ & $0.41^{*}$ & 1 & 5.79 \\
\hline
\end{tabular}

Table 2. Correlation Matrix for Inclusive Growth, Institutions, and Financial Development

vector is positive for law and order only, while liquid liability, market capitalization, corruption, credit to private sector and investment profile were negative. This result is quite interesting. For instance, the coefficient for level of corruption will have a positive relationship with inclusive growth when it is written in equation form. This suggests that with increasing level of corruption in Nigeria inclusive growth will increase by 0.019 . The institutional quality variable of law and order has negative impact on inclusive growth. This suggests that the maintenance of law and order in Nigeria is low and it thus has negative consequences on the Nigerian economy.

Table 5 (see Appendix-III) reports results for the estimated TAR and the MTAR model. The $\rho_{1}$ and $\rho_{2}$ estimates are presented, with the $\phi_{u}$ statistics for null hypothesis of no asymmetric cointegration, $\mathrm{H}_{0}:\left(\rho_{1}=\rho_{2}=0\right)$ and the standard $f$-statistic test for the null hypothesis of symmetric cointegration, $\mathrm{H}_{0}$ : $\left(\rho_{1}=\rho_{2}\right)$. It is evident from Table 5 that the estimates of $\rho_{1}$ and $\rho_{2}$ are negative which are anticipated for stationarity of the error term. For the TAR model, the asymmetric cointegration for the null hypothesis of $\mathrm{H}_{0}:\left(\rho_{1}=\rho_{2}=0\right)$ with a statistic of 5.965 was not rejected at 1 percent level of significance. The null hypothesis of symmetric adjustment $\mathrm{H}_{0}$ : $\left(\rho_{1}=\rho_{2}\right)$ with a value of 0.826 could not be rejected because of its non-significance at any level. In addition, the results indicate that $\left|\rho_{1}\right|>\left|\rho_{2}\right|$ that is 0.614 is greater than 0.481 , which implies that inclusive growth is quicker upward than downward. 


\section{Yinusa et al.}

As for the MTAR models, the estimates of the autoregressive decay, $\rho_{1}$ and $\rho_{2}$ have negative signs. The test for asymmetric cointegration for the null hypothesis of $\mathrm{H}_{0}:\left(\rho_{1}=\rho_{2}=0\right)$ with a value of 13.615 was rejected at 1 percent level of significance, while the null of symmetric cointegration $\mathrm{H}_{0}:\left(\rho_{1}=\rho_{2}\right)$ with $f$-statistic of 11.976 was also rejected at 1 percent level of significance. This is consistent with the results obtained from the Johansen and Engle-Granger test that the null hypothesis of no cointegration was rejected. In addition, $\left|\rho_{1}\right|>\left|\rho_{2}\right|, 0.762$ is greater than 0.684 , this implies that inclusive growth is quicker upward than when it is reducing.

It is clear from the reported TAR and the MTAR results that all the conditions are fulfilled in the MTAR model, that is, there is the presence of non-linear cointegration, the null hypothesis $H_{0}:\left(\rho_{1}=\rho_{2}\right.$ $=0$ ) was rejected and the null hypothesis $\mathrm{H}_{0}:\left(\rho_{1}=\rho_{2}\right)$; of symmetric adjustment were also rejected. The implication of this is that adjustment is asymmetric for inclusive growth, institutional quality and financial development in Nigeria and that the MTAR specification has superior power properties than the Engle-Granger or any other linear cointegration test.

The reliability of the estimates was ascertained using the Ramsey's RESET statistics for linearity, the Lagrange multiplier (LM) serial correlation test, the Breusch-Pagan-Godfrey (BPG) test for Heteroscedasticity, Jarque-Bera test for non-normality and the cumulative sum (CUSUM) and cumulative sum of square (CUSUMSQ) stability tests. The five tests revealed that the successive error terms of the estimated model are not correlated, the model was correctly specified, the disturbance terms are homoscedastic, the estimated model follows a normal distribution and that the estimated model is stable.

Since cointegration exists and also that each cointegrating relationship is described by asymmetric adjustment, then asymmetric error-correction models for the relationship was estimated. These are reported in Table 6 (see Appendix-IV).

The results in Table 6 report the point estimates of $\rho_{11}$ and $\rho_{12}$, which determines the speed of adjustment for positive and negative deviations for long-run relationship between inclusive growth, institutional quality, and financial development. Results further showed that estimates of $\rho_{11}$ and $\rho_{12}$ adjust back to equilibrium. However, the $t$-statistic for the error correction indicates that the inclusive growth adjusts to both positive and negative discrepancy. The result also shows that the inclusive growth adjusts faster in the positive discrepancy than the negative one. The adjustment mechanism shows that when inclusive growth is rising, deviations from equilibrium are corrected at a higher rate; about 54.8 percent of the deviations are corrected yearly while about 25.1 percent of the deviations are corrected yearly when inclusive growth is falling. 
In addition, there is evidence that in the short-run, corruption, and law and order have negative relationship with inclusive growth. The implication of this result is that corruption, and the law and order in Nigeria adversely affect inclusive growth in Nigeria. This is occasioned by political instability, large scale corruption in the public sector, and insurgency in the Niger Delta region; as well as Boko Haram militancy in the North Eastern part of Nigeria. In addition, there is evidence that in the current year market capitalization, credit to the private sector and investment profile have positive significant relationship with inclusive growth in Nigeria in the short-run.

\section{Hypothesis Testing}

Testing the research hypotheses of the study, both the long-run and the short-run estimates reported in Tables 4 and 6 were used. The first hypothesis $\left(H_{01}\right)$ states that financial development does not increase the level of inclusive growth in Nigeria. From the cointegrating vector reported in Table 4 for the Johansen and Juselius cointegration test and the vector error correction model reported in Table 6. There is evidence that the proxy of financial development (credit to the private sector, liquid liabilities, and market capitalization) have positive relationship with inclusive growth. Thus, the null is rejected and the alternative hypothesis that financial development increases the level of inclusive growth in Nigeria is accepted. This result is in conformity with the work of Abedifar et al. (2016), Law et al. (2013), and Peia and Roszbach (2015) who found that financial development accelerates the level of growth.

Hypothesis two $\left(\mathrm{H}_{02}\right)$ states that institutional quality does not improve the level of inclusive growth in Nigeria. Table 4 and 6 show the evidence that the proxy of institutional quality (investment profile) has positive and significant relationship with inclusive growth in Nigeria. Thus, the null hypothesis that institutional quality does not improve the level of inclusive growth in Nigeria is rejected, while the alternative hypothesis that institutional quality improves the level of inclusive growth in Nigeria is accepted. This result is in line with Demetriades and Law (2004), Garretsen et al. (2004), and Law et al. (2013) who found that institutional quality enhances the level of growth.

\section{DISCUSSION}

Findings from this study are insightful as there is evidence of symmetric and asymmetric cointegrating relationship between institutional quality, financial development, and inclusive growth in Nigeria. Using the symmetric cointegration, there is evidence of a long-run cointegrating relationship between the inclusive growth, institutional quality, and financial development in Nigeria. This study is in accord with the study of Ferrini (2012) who asserts that institutions also spur growth through economic transactions. He argues that the costs of economic transactions propel economic growth in the form 


\section{Yinusa et al.}

of contracts and contract enforcement, common commercial codes, and increased availability of information, all of which reduce the costs of transactions, risk, and uncertainty, and thus increase the level of growth. In addition, there is evidence of an asymmetric cointegrating relationship between institutional quality, financial development, and inclusive growth. This study further emphasized the institutional hypothesis. The result is similar to the conclusion of Alexious et al. (2014) who found that the quality of the institutional environment is one of the most important factors defining economic prosperity.

Furthermore, the result shows that the inclusive growth adjusts faster in the positive discrepancy than the negative one. This study is in conformity with the work of Law and Singh (2014) who found that there is a threshold effect in finance-growth relationship and that the Level of financial development is beneficial to a certain threshold; beyond the threshold level, further development of finance tends to affect growth adversely. They therefore suggest an optimal level of finance that is more crucial for economic growth.

\section{CONCLUSION}

This paper examined the relationship between inclusive growth, institutional quality, and financial development in Nigeria. The paper applied the threshold autoregressive (TAR) and the momentum threshold autoregressive (MTAR) models developed by Enders and Siklos (2001), which accommodate non-linearity and asymmetric adjustment between series. The results show that the behavior of these series exhibit asymmetries relationship between inclusive growth, institutional quality, and financial development in Nigeria and this is in conformity with the institutional quality hypothesis. This is not surprising as financial development and growth in are generally ad hoc and the financial markets are not fully developed.

Symmetric cointegration tests of Engle and Granger, and Johansen found presence of long-run relationship between inclusive growth, institutional quality, and financial development in Nigeria. However, when the TAR and MTAR model were used, long-run relationships between the series used the MTAR model. Results from the MTAR model revealed that asymmetric cointegrating relationship exists in Nigeria and that the asymmetric error correction term shows that inclusive growth adjust to both the positive and negative discrepancy. In addition, the economic structures of Nigeria might be a factor for the asymmetric adjustment found in the results.

\section{IMPLICATIONS}

The findings of this study bring significant theoretical and practical implications for investors and policy 
makers. The theoretical implication of this study is that the study found support for the institutional quality hypothesis; this implies that the Nigerian government should strive to have good institutional quality as it is positively correlated with economic growth.

From the practical implications view, the followings are suggested: first, market capitalization a proxy for financial development is positive and significant. Thus, there is the need for increased capital market involvement in Nigeria in order to continue to accelerate the level of growth in Nigeria. Second, two measures of institutional quality: corruption, and law and order have negative relationship with inclusive growth in Nigeria. This is a reflection of the extra-judicial killings, militancy, as well as insurgency experienced in some parts of the country. Thus, there is the need for the Nigerian government to continue to combat the insurgence activities in the Niger Delta and the Northeast of Nigeria to propel growth. Fourth, it is particularly worrisome that the level of corruption is positively related to inclusive growth in the long-run for Nigeria; this implies that increases in the level of corruption in Nigeria will have a multiplier effect on growth. However, the positive effect would be harmful to the economy, and thus government should continue to engage in aggressive fight against corruption. The anti-corruption agencies in Nigeria should be strengthened and well-funded to eliminate corruption in Nigeria.

\section{LIMITATIONS AND FUTURE DIRECTIONS}

The major limitation of this study is that it focused on Nigeria to examine the nexus between financial development, institutional quality, and inclusive growth. Researchers interested in examining this relationship should conduct a longitudinal study into different continent or do a comparative analysis between countries as this is capable of providing a more strong and robust empirical findings. Future studies should also make use of other asymmetric cointegration techniques such as the Hansen and Seo (2002) threshold cointegration or the exponential Smooth transition autoregressive model of Terasvirta (1994).

\section{REFERENCES}

Abedifar, P., Hassan, I. \& Tarazi, A. (2016). Finance-growth nexus and dual-banking systems:Relative importance of Islamic banks. Journal of Economic Behaviour and Organization, 132, 198-215. https://doi.org/10.1016/j.jebo.2016.03.005

Acemoglu, D., Aghion, P., Griffith, R. \& Zilibotti, F. (2003). Technology, hold-up, and vertical integration: What do we learn from micro data? London: Mimeo, IFS.

Adeyeye, P. O., Fapetu, O., Aluko, O. A. \& Migiro, S. O. (2015). Does supply-leading hypothesis hold in a developing economy? A Nigerian focus. Procedia Economics and Finance. 30, 30-37. https://doi.org/10.1016/S2212-5671(15)012526

Akinlo, A. E. \& Akinlo, O. O. (2009). Stock market development and economic growth: evidence from seven Sub-Saharan African countries. Journal of Economics and Business 61, 162-171. https://doi.org/10.1016/j.jeconbus.2008.05.001

Akinlo, A. E. \& Egbetunde, T. (2010). Financial development and economic growth: the experience of 10 Sub-Saharan African countries revisited. The Review of Finance and Banking, 2(1): 17-28.

Alaabed, A. \& Masih, M. (2016). Finance-growth nexus: Insights from an application of threshold regression model to Malaysia's dual financial system. Borsa Instanbul Review, 16(2): 63-71. https://doi.org/10.1016/j.bir.2016.01.004 


\section{Yinusa et al.}

Allen, F. \& Gale, D. (1999). Bubbles, rises, and policy. Oxford Review of Economic Policy, 15(3): 9-18.

Alexious, C., Tsaliki, P. \& Osman, H. R. (2014). Institutional quality and economic growth: empirical evidence from Sudanese economy. Economic Annals, 59(203): 119-137. https://doi.org/10.2298/EKA14031191

Allen, F., Qian, J. \& Qian, M. J. (2005). Law, finance, and economic growth in China. Journal of Financial Economics, 77(1): 57-116. https://doi.org/10.1016/j.jfineco.2004.06.010

Al-Tamimi, H. H., Al-Awad, M. \& Charif, H.A. (2002). Finance and Growth: Evidence from some Arab Countries. Journal of Transnational Management Development, 7(2): 3-18. https://doi.org/10.1300/J130v07n02_02

Al-Yousif, Y. K. (2002). Financial development and economic growth: another look at the evidence from developing countries. Review of Financial Economics, 11, 131-150. https://doi.org/10.1016/S1058-3300(02)00039-3

Andini, M. \& Andini. C. (2014). Finance, growth and quantile parameter heterogeneity. Journal of Macroeconomics, 40, 308322. https://doi.org/10.1016/j.jmacro.2014.01.008

Ang, J. B. (2008). A survey of recent developments in the literature of finance and growth. Journal of Economic Surveys, 22(3): 536-576. https://doi.org/10.1111/j.1467-6419.2007.00542.x

Arestis, P. \& Demetriades, P. (1996). Finance and growth: Institutional considerations and causality. Department of Economics Working Paper No. 5, University of East London.

Atje, R. \& Jovanovic, B. (1993). Stock markets and development. European Economic Review, 37(2-3): 632-640. https://doi.org/10.1016/0014-2921(93)90053-D

Beck, T. \& Levine, R. (2002). Industry growth and capital allocation: Does having a market- or bank-based system matter? Journal of Financial Economics, 64(2): 147-180. https://doi.org/10.1016/S0304-405X(02)00074-0

Bittencourt, M. (2012). Financial development and economic growth in Latin America: Is Schumpeter right? Journal of Policy Modeling, 34(3): 341-355.

Boot, A. W. A. \& Thakor, A. (1997). Financial system architecture. Review of Financial Studies, 10(3): 693-733. https://doi.org/10.1093/rfs/10.3.693

Boulila, G. \& Trabelsi. M. (2004). The causality issue in the finance and growth nexus: empirical evidence from Middle East and North African countries. Review of Middle East Economics and Finance, 2(2): 123-138.

Breitenlechner, M., Gachter, M. \& Sindermann, F. (2015). The Finance-Growth nexus in Crisis. Economics Letters, 132, $31-33$. https://doi.org/10.1016/j.econlet.2015.04.014

Calderón, C. \& Liu, L. (2002). The direction of causality between financial development and economic growth. Journal of Development Economics, 72(1): 321-334. https://doi.org/10.1016/S0304-3878(03)00079-8

Caporale, G. M., Rault, C., Sova, A. D. \& Sova, R. (2014). Financial development and economic growth: Evidence from 10 new European Union members. International Journal of Finance and Economics, 20(1): 48-60. https://doi.org/10.1002/ijfe.1498

Catrinescu, N., Leon-Ledesma, M., Piracha, M. \& Quillin. B. (2009). Remittances, institutions, and economic growth. World Development, 37(1): 81-92. https://doi.org/10.1016/j.worlddev.2008.02.004

Chan, K. S (1993). Consistency and limiting distribution of the least squares estimator of threshold autoregressive model. The Annals of Statistics, 21, 520-533.

Chang, T. (2002). Financial development and economic growth in Mainland China: a note on testing Demand-following and Supply-leading hypothesis. Applied Economics Letters, 9(13): 869-873. https://doi.org/10.1080/13504850210158962

Chang. T. \& Caudill. S. B. (2005). Financial development and economic growth: the case of Taiwan. Applied Economics, 37(12): 1329-1335. https://doi.org/10.1080/0003684042000338702

Chen, K. C., Wu, L. \& Wen. J. (2013). The relationship between finance and growth in China. Global Finance Journal, $24,1-12$. https://doi.org/10.1016/j.gfj.2013.03.006

Chinaemerem, A. \& Chigbu, P. (2012). An evaluation of financial development and economic growth of Nigeria: A causality test. Kuwait Chapter of Arabian Journal of Business and Management Review, 1(10): 27-44.

Christopoulos, D. \& Tsionas, E. (2004). Financial development and economic growth: evidence from panel unit root and cointegration tests. Journal of Development Economics, 73(1): 55-74. https://doi.org/10.1016/j.jdeveco.2003.03.002

Demetriades, P. \& Andrianova, S. (2004). Finance and growth: what we know and what we need to know. Financial development and economic growth: 38-65. London: Palgrave Macmillan.

Demetriades, P. \& Law, S. H. (2004). Finance, institutions and economic development. International Journal of Finance and Economics, 11(3): 245-260. https://doi.org/10.1002/ijfe.296

Demirgüç-Kunt, A. \& Levine, R. (1999). Bank-based and market-based financial systems: Cross-country comparisons. The World Bank.

Easterly, W., Levine, R. \& Roodma, D. (2004). Aid, policies, and growth: Comments. American Economic Review, 94(3): 774780.

Enders, W \& Siklos, P. L. (2001). Cointegration and Threshold Adjustment. Journal of Business and Economic Statistics, 19(2): 166-176. https://doi.org/10.1198/073500101316970395

Ferrini, L. (2012). The Importance of institutions to economic development. University of Reading: Mimeo.

Garretsen, H., Lensink, R. \& Sterken. E. (2004). Growth, financial development, societal norms and legal institutions. Journal of International Financial Markets, Institutions and Money, 14(2): 165-183. https://doi.org/10.1016/j.intfin.2003.06.002

Gazdar, K. \& Cherif, M. (2015). Institutions and the finance-growth nexus: Empirical evidence from MENA countries. Borsa Istanbul Review, 15 (3): 137-160. https://doi.org/10.1016/j.bir.2015.06.001

Goldsmith, R. W. (1969). Financial structure and development. New Haven: Yale University Press.

Greenwood, J. \& Jovanovic. B. (1990). Financial development, growth, and the distribution of Income. Journal of Political Economy, 98(5): 1076-1108. https://doi.org/10.1086/261720 
Grundler, K. \& Weitzel, J. (2013). The financial sector and economic growth in a panel of countries. Discussion Paper Series 123, Julius Maximilian University of Würzburg, Chair of Economic Order and Social Policy.

Gurley, J. G. \& Shaw, E. (1955). Financial aspects of economic development. American Economic Review, 45(3): 515-538.

Hansen, B. E. \& Seo, B. (2002). Testing for two-regime threshold cointegration in vector error-correction models. Journal of Econometrics, 110(2): 293-318. https://doi.org/10.1016/S0304-4076(02)00097-0

Herwatz, H. \& Walle, Y. M. (2014). Openness and finance-growth nexus. Journal of Banking and Finance, 48, $235-247$. https://doi.org/10.1016/j.jbankfin.2014.06.031

Jalil, A. \& Feridun, M. (2011). Impact of financial development on economic growth: empirical evidence from Pakistan. Journal of the Asia Pacific Economy, 16(1): 71-80. https://doi.org/10.1080/13547860.2011.539403

Jung, W. S. (1986). Financial development and economic growth: International evidence. Economic Development and Cultural Change, 34(2): 333-346. https://doi.org/10.1086/451531

King, R. G. \& Levine, R. (1993). Finance, entrepreneurship, and growth: theory and evidence. Journal of Monetary Economics, 32, 513-542.

Kirkpatrick, C. (2000). Financial development, economic growth, and poverty reduction. Pakistan Development Review, 39(4): 363-368.

Law, S. H., Azman-Saini, W. N. W. \& Ibrahim, M. H. (2013). Institutional quality thresholds and the finance-growth nexus. Journal of Banking and Finance, 37(12): 5373-5381. https://doi.org/10.1016/j.jbankfin.2013.03.011

Law. S. H. \& Singh. N. (2014). Does too much finance harm economic growth? Journal of Banking and Finance, 41, 36-44. https://doi.org/10.1016/j.jbankfin.2013.12.020

Levine, R. \& Zervos, S. (1998). Stock markets, banks, and economic growth. American Economic Review, 88(3): 537-558.

Maduka, K. O. \& Onwuka, A. C. (2013). Financial market structure and economic growth: evidence from Nigeria data. Asian Economic and Financial Review, 3(1): 75-98.

Mckinnon, R. I. (1973). Money and capital in economic development. Washington: Brookings Institution.

Murinde, V. \& Eng, F. S. H. (1994). Financial development and economic growth in Singapore: demand-following or supplyfollowing? Applied Financial Economics, 4, 391-404. https://doi.org/10.1080/758518671

Muye, I. M. \& Muye, I. Y (2017) Testing for causality among globalization, institution and fnancial development: further evidence from three economic blocs. Borsa Istanbul Review, 17(2):117- 132

Nkoro, E. \& Uko, A. K. (2013). Financial sector development- economic growth nexus: empirical evidence from Nigeria. American Journal of Contemporary Research, 3(2): 87-94.

North, D. C. (1990). Institutions, institutional change, and economic performance. New York: Cambridge University Press.

Nyasha, S., Gwenhure, Y. \& Odhiambo. N. M. (2016). Financial development and economic growth in Ethiopia: a dynamic causal linkage. UNISA Economic Research Working Paper Series, 06/2016.

Odhiambo. N. M. (2004). Is financial development still a spur to economic growth? A causal evidence from South Africa. Savings and Development, 28(1): 47-62.

Odhiambo. N. M. (2008). Financial development in Kenya: a dynamic test of the finance-led growth hypothesis. Economic Issues, 13(2): 21-36.

Odhiambo, N. M. (2009). Finance-growth-poverty nexus in South Africa: A dynamic causality linkage. The Journal of SocioEconomics, 38(2): 320-325. https://doi.org/10.1016/j.socec.2008.12.006

Oyinlola, M. A. \& Adedeji, A. (2019). Human capital, financial sector development and Inclusive growth in sub-Saharan Africa, Economic Change Restructuring, 52(1): 43-66.

Pan, H. \& Wang, C. (2013). Financial development and economic growth: A new investigation. Journal of Economics Development. 38(1): 27-46.

Patrick, H. (1966). Financial development and economic growth in underdeveloped countries. Economic Development and Cultural Change, 14(2): 174-189. https://doi.org/10.1086/450153

Peia, O. \& Roszbach, K. (2015). Finance and growth: Time series evidence on causality. Journal of Financial Stability, 19, 105118. https://doi.org/10.1016/j.jfs.2014.11.005

Raheem, I. D., Kazeem, O. I. \& Adedeji, A. A. (2018). Inclusive growth, human capital development, and natural resource rent in SSA, Economic Change Restructuring, 51: 29-48

Robinson, J. (1952). The generalization of the general theory. The rate of interest and other essays. London: MacMillan.

Rigobon, R. \& Rodrik, D. (2004). Law and order, Democracy, Openness and Income: Estimating the Interrelationships. NBER Working paper 10750 .

Schumpeter, J. A. (1911). The theory of economic development. Cambridge, Mass: Harvard University Press.

Singh, A. (1999). Should Africa promote stock market capitalism? Journal of International Development, 11, 343-365. https://doi.org/10.1002/(SICI)1099-1328(199905/06)11:3<343::AID-JID593>3.0.CO;2-Q

Shan, J., Morris, A. \& Sun, F. (2001). Financial development and economic growth: An egg-and-chicken Problem? Review of International Economics, 9(3): 443-454. https://doi.org/10.1111/1467-9396.00291

Shaw, E. S. (1973). Financial deepening in economic development. New York: Oxford University Press.

Terasvirta, T. (1994). Specification, estimation, and evaluation of Smooth Transition Autoregressive Models. Journal of the American Statistical Association, 89(425): 208-218. https://doi.org/10.1080/01621459.1994.10476462

Todaro, S. C. \& Smith, M. P. (2011). Economic Development, 11 th edition. London: Pearson Education Publishing.

Waqabaca, C. (2004). Financial development and economic growth in Fiji. Working Paper 2004/03, Economics Department, Reserve Bank of Fiji.

World Bank (2009). World Development Indicators.

World Bank (2014). World Development Indicators. 
Yinusa et al.

Appendix-1

\begin{tabular}{ccc}
\hline Variables & ADF & PP \\
\hline LGDPPPE & -1.708 & -1.744 \\
$\Delta$ LGDPPPE & $-5.601^{* *}$ & $-5.606^{* *}$ \\
CPS & -2.078 & -2.064 \\
$\Delta$ CPS & $-6.049^{* *}$ & $-6.049^{* *}$ \\
LLB & 0.039 & -1.269 \\
$\Delta$ LLB & $-5.935^{* *}$ & $-5.935^{* *}$ \\
MCAP & -1.845 & -1.686 \\
$\Delta$ MCAP & $-6.312^{* *}$ & $-8.582^{* *}$ \\
CORRP & -2.155 & -1.457 \\
$\Delta$ CORRP & $-3.959^{* *}$ & $-3.966^{* *}$ \\
INVP & -2.546 & -2.706 \\
$\Delta$ INVP & $-6.333^{* *}$ & $-6.520^{* *}$ \\
LAW & -2.493 & -1.878 \\
$\Delta$ LAW & $-3.486^{*}$ & $-3.435^{*}$ \\
\hline
\end{tabular}

Source: Authors' Computation

Note: $* *$ and $*$ denote level of significance at $1 \%$ and $5 \%$, respectively.

Table 3. Unit Root Tests 
Panel A (Dependent Variable: LGDPPPE)

\begin{tabular}{ccccc}
\hline $\mathbf{H}_{\mathbf{0}}$ & $\mathbf{H}_{\mathbf{1}}$ & Test Stat & $\mathbf{C V}$ & Results \\
\hline Jtrace & & & & \\
$\mathrm{r}=0$ & $\mathrm{r}>0$ & $191.46^{*}$ & 159.53 & Reject $\mathrm{H}_{0}$ \\
$\mathrm{r} \leq 1$ & $\mathrm{r}>1$ & 124.58 & 125.62 & \\
$\mathrm{r} \leq 2$ & $\mathrm{r}>2$ & 88.51 & 95.75 & Do not reject $\mathrm{H}_{0}$ \\
$\mathrm{r} \leq 3$ & $\mathrm{r}>3$ & 53.30 & 69.82 & Do not reject $\mathrm{H}_{0}$ \\
$\mathrm{r} \leq 4$ & $\mathrm{r}<4$ & 27.88 & 47.86 & Do not reject $\mathrm{H}_{0}$ \\
$\mathrm{r} \leq 5$ & $\mathrm{r}<5$ & 15.43 & 29.80 & Do not reject $\mathrm{H}_{0}$ \\
$\mathrm{r} \leq 6$ & $\mathrm{r}<6$ & 5.23 & 15.49 & Do not reject $\mathrm{H}_{0}$ \\
$\mathrm{r} \leq 7$ & $\mathrm{r}<7$ & 0.51 & 3.84 & Do not reject $\mathrm{H}_{0}$ \\
$\mathrm{Jmax}$ & & & & Do not reject $\mathrm{H}_{0}$ \\
$\mathrm{r}=0$ & $\mathrm{r}>0$ & $66.88^{*}$ & 52.36 & \\
$\mathrm{r} \leq 1$ & $\mathrm{r}>1$ & 36.07 & 46.23 & Reject $\mathrm{H}_{0}$ \\
$\mathrm{r} \leq 2$ & $\mathrm{r}>2$ & 35.21 & 40.08 & Do not reject $\mathrm{H}_{0}$ \\
$\mathrm{r} \leq 3$ & $\mathrm{r}<3$ & 25.42 & 33.88 & Do not reject $\mathrm{H}_{0}$ \\
$\mathrm{r} \leq 4$ & $\mathrm{r}<4$ & 12.45 & 27.58 & Do not reject $\mathrm{H}_{0}$ \\
$\mathrm{r} \leq 5$ & $\mathrm{r}<5$ & 10.20 & 21.13 & Do not reject $\mathrm{H}_{0}$ \\
$\mathrm{r} \leq 6$ & $\mathrm{r}<6$ & 4.71 & Do not reject $\mathrm{H}_{0}$ \\
$\mathrm{r} \leq 7$ & $\mathrm{r}<7$ & 0.51 & 3.84 & Do not reject $\mathrm{H}_{0}$ \\
\hline $\mathrm{Pane}$ & & & Do not reject $\mathrm{H}_{0}$ \\
\hline
\end{tabular}

Panel B: Cointegrating Vectors

\begin{tabular}{ccccccc}
\hline LGDPPPE & LAW & CPS & CORRP & INVP & LLB & MCAP \\
1.000 & 0.294 & -0.790 & -0.019 & -0.151 & -1.769 & -3.072 \\
\hline
\end{tabular}

Panel C: Engle-Granger Cointegration Test

$P \quad$ AIC Lags

$\begin{array}{lll}-1.049(-5.037) & 47.089 & 2\end{array}$

Source: Authors' Computation

Note: The critical values of t-statistics for the null hypothesis $p=0$ with two variables in the cointegrationg relationship are $-4.00,-3.37$ and-3.02; * denotes level of significance at $5 \%$.

Table 4. Estimated Long-Run Parameters of Inclusive Growth, Institutions and Financial Development 


\begin{tabular}{ccc}
\hline Parameter & TAR Consistent $\emptyset_{u}$ & MTAR Consistent $\emptyset^{*}{ }_{u}$ \\
\hline$P_{1}$ & $-0.614(-2.826)^{* *}$ & $-0.762(-3.594)^{* *}$ \\
$P_{2}$ & $-0.981(-2.525)^{*}$ & $-0.684(-2.769)^{* *}$ \\
Tests & & \\
\hline $\mathrm{H}_{0}: \mathrm{F}\left(P_{l}=P_{2}=0\right)$ & 5.965 & $13.615^{* *}$ \\
$\mathrm{H}_{0}: \mathrm{F}\left(P_{l}=P_{2}\right)$ & 0.826 & $11.976^{* *}$ \\
Threshold & -0.233 & -0.044 \\
AIC & 38.881 & 26.083 \\
Diagnostic Tests & Stat $($ Prob) & Stat $($ Prob) \\
\hline LM-test for serial correlation & $2.446(0.122)$ & $6.249(0.181)$ \\
Ramsey RESET test for non-linearity & $2.966(0.563)$ & $5.769(0.217)$ \\
BPG test for Heteroscedasticity & $3.993(0.335)$ & $2.846(0.241)$ \\
Jarque-Bera test for non-normality & $4.106(0.128)$ & $4.106(0.128)$ \\
CUSUM test & Stable & Stable \\
CUSUMSQ test & Stable & Stable \\
\hline
\end{tabular}

Source: Authors' Computation

Note: $* *$ and $*$ denote level of significance at $1 \%$ and $5 \%$, respectively. Critical values are obtained from (Wane et al. 2004). The $t$-statistic the probability values are in parenthesis. CUSUM and CUSUMSQ tests are applied to the residuals to test for stability of all coefficients.

Table 5. Estimates for Asymmetric Cointegration 
Dependent Variable: LGDPPPE

\begin{tabular}{ccccc}
\hline Variable & Coefficient & Std. Error & $\boldsymbol{t}$-Statistic & Prob. \\
\hline$P_{11}$ & $-0.548^{* *}$ & 0.102 & -5.379 & 0.000 \\
$P_{12}$ & $-0.251^{*}$ & 0.092 & -2.729 & 0.023 \\
C & -0.026 & 0.037 & -0.711 & 0.495 \\
D(LAW) & -0.053 & 0.065 & -0.804 & 0.442 \\
D(CPS) & $0.383^{*}$ & 0.122 & 3.140 & 0.012 \\
D(CPS(-1) $)$ & -0.061 & 0.093 & -0.655 & 0.529 \\
D(CORRP) & -0.096 & 0.082 & -1.171 & 0.272 \\
D(CORRP(-1) & -0.080 & 0.074 & -1.081 & 0.308 \\
D(INVP) & $0.089^{*}$ & 0.034 & 2.610 & 0.028 \\
D(LLB) & 0.060 & 0.045 & 1.344 & 0.212 \\
D(LLB(-1) & $0.723^{* *}$ & 0.130 & 5.555 & 0.000 \\
D(MCAP) & $0.279^{* *}$ & 0.075 & 3.730 & 0.005 \\
D(MCAP(-1) & -0.147 & 0.123 & -1.190 & 0.265 \\
\hline Sourc: & & & & \\
\hline
\end{tabular}

Source: Authors' Computation

Note: $* *$ and $*$ denote level of significance at $1 \%$ and $5 \%$, respectively. $\rho_{11}$ and $\rho_{12}$ are the error correction terms for negative and positive residuals, respectively.

Table 6. Asymmetric Error-Correction Models 